\title{
Elevated serum parathyroid hormone related protein and 1,25-dihydroxycholecalciferol in hypercalcaemia associated with adult T-cell leukaemia-lymphoma
}

\author{
S.R.D. Johnston and P.J. Hammond
}

Department of Medicine, Royal Postgraduate Medical School, Hammersmith Hospital, Du Cane Road, London W12 OHS, UK

\begin{abstract}
Summary: Hypercalcaemia occurs in up to $80 \%$ of patients with adult T-cell leukaemia-lymphoma (ATLL) associated with human T-cell leukaemia virus-1 infection. Elevated serum levels of 1,25dihydroxycholecalciferol, implicated in the pathogenesis of hypercalcaemia in lymphoma, and of parathyroid hormone-related protein (PTHrP), which is associated with hypercalcaemia of several solid malignancies, were demonstrated in a patient with ATLL hypercalcaemia. Treatment with bisphosphonates reduced the serum calcium but had no significant effect on the serum PTHrP levels. This case supports recent in vitro evidence for enhanced PTHrP expression in ATLL tumour cells and suggests that more than one tumour cell product may be involved in the pathogenesis of ATLL hypercalcaemia.
\end{abstract}

\section{Introduction}

Hypercalcaemia is a common finding in adult T-cell leukaemia lymphoma (ATLL). ${ }^{1}$ A variety of tumour cell products have been implicated in the development of ATLL hypercalcaemia. Increased circulating concentrations of 1,25-dihydroxycholecalciferol (DHCC) have been associated with hypercalcaemia occurring in both Hodgkin's disease $^{2}$ and non-Hodgkin's lymphoma. ${ }^{3}$ Ectopic production of DHCC has been shown in human T-cell leukaemia virus-1 (HTLV-1) transformed lymphocytes ${ }^{4}$ suggesting that it also may become involved in the pathogenesis of hypercalcaemia in HTLV-1 associated ATLL.

The demonstration of parathyroid hormonerelated protein (PTHrP) messenger RNA in various solid tumours complicated by hypercalcaemia implies that this peptide may play a major role in humoral hypercalcaemia of malignancy. ${ }^{5}$ Circulating serum PTHrP has been detected by radioimmunoassay in some patients with solid tumours associated with malignant hypercalcaemia including lung, breast and head and neck cancer. ${ }^{6}$ Evidence for the role of PTHrP in haematological malignancies is less clear cut. Although there has been increasing in vitro evidence for PTHrP expression in ATLL, there has

Correspondence: S.R.D. Johnston, M.R.C.P., Department of Academic Biochemistry, Royal Marsden Hospital, Fulham Road, London SW3 6JJ, UK.

Accepted: 24 February 1992 been little evidence for elevated serum levels in these patients. We report a case of hypercalcaemia in HTLV-1-associated ATLL in whom both the serum PTHrP and DHCC were found to be elevated and discuss the evidence implicating their role in the pathogenesis of ATLL hypercalcaemia.

\section{Case report}

A 52 year old woman from Guyana was admitted to hospital with bilateral facial nerve weakness, drowsiness and dehydration. Investigations revealed hypercalcaemia, with a serum calcium of $4.68 \mathrm{mmol} / \mathrm{l}$ and serum phosphate of $1.73 \mathrm{mmol} / \mathrm{l}$. Further investigations showed a leucoerythroblastic blood film, with a peripheral lymphocyte count of $38,000 / \mathrm{mm}^{3}$. Serology for HTLV-1 was positive, and a bone marrow examination confirmed adult T-cell lymphoma with CD4 + /CD8 - T cells expressing the CD25 (TAC) antigen. In addition, marked osteoclast activity with bone resorption was seen.

The plasma urea and electrolytes were normal and the serum angiotensin converting enzyme was 32 IU/1 (normal range $<52$ IU/1). Serum parathyroid hormone $(\mathrm{PTH})$ was undetectable. The 25hydroxycholecalciferol level was suppressed at $5.40 \mathrm{ng} / \mathrm{ml}$ (normal range $7-50 \mathrm{ng} / \mathrm{ml}$ ), with the 1,25-dihydrocholecalciferol (DHCC) level elevated at $78 \mathrm{pg} / \mathrm{ml}$ (normal range $20-65 \mathrm{pg} / \mathrm{ml}$ ). The serum PTHrP (1-86) measured by radioimmunoassay was significantly elevated at $0.9 \mathrm{pmol} / \mathrm{l}$ (nor- 
mal range $<0.23 \mathrm{pmol} / \mathrm{l})$. After rehydration with was given. After 48 hours the calcium was lowered to $2.07 \mathrm{mmol} / 1$ with a serum phosphate of 0.41 $\mathrm{mmol} / \mathrm{l}$. Repeat measurement of the serum PTHrP showed persistent elevation at $0.51 \mathrm{pmol} / \mathrm{l}$.

Although her general condition improved with treatment of the hypercalcaemia, she subsequently developed hyperinfection with Strongyloides stercoralis. She died 30 days after admission.

\section{Discussion}

A number of mediators of the humoral hypercalcaemia of malignancy (HMM) have been proposed including parathyroid hormone-related protein cholecalciferol (DHCC). ${ }^{7}$ Cytokines appear to be more important in the development of local osteolytic hypercalcaemia resulting from metastatic disease. Cells of the monocytic-macrophage line are capable of converting 25-hydroxycholecalciferol to DHCC, and elevated levels of DHCC have been found in association with lymphomas, ${ }^{3}$ with synthesis of DHCC demonstrated in tumour cells. ${ }^{8}$ Since its isolation in 1987 it has become apparent that PTHrP is a common mediator of the HMM syndrome, with elevated serum levels found in $48-71 \%$ of solid tumours associated with HHM. ${ }^{6}$ In breast cancer, $92 \%$ of hypercalcaemic patients with bone metastases have elevated serum levels of PTHrP compared with $36 \%$ of normocalcaemic patients with bone metastases and $9 \%$ of normocalcaemic patients without bone metastases. ${ }^{9}$ Elevated serum levels of PTHrP are less common in HMM associated with haematological malignancies occurring in $30 \%$ of patients with myeloma ${ }^{6}$ and in four out of five patients with lymphoma in Kao's study. ${ }^{10}$

The incidence of hypercalcaemia in patients with HTLV-1-associated adult T-cell leukaemia-lymphoma is about $80 \%$ and, although the aetiology has not been fully elucidated, DHCC levels are often found to be suppressed. ${ }^{11}$ There has been increasing normal saline disodium pamidronate $(60 \mathrm{mg}$ i.v.) (PTHrP), various cytokines and 1,25-dihydroxy-

evidence implicating a role for PTHrP. Recently, 는 immunocytochemical demonstration of PTHrP $\stackrel{\square}{Q}$ protein has been reported in lymphoblastic tissue $C$. from patients with ATLL. ${ }^{12}$ Previous in vitro $\overrightarrow{\vec{F}}$ studies have demonstrated expression of PTHrP $\stackrel{?}{+}$ messenger RNA in both HLTV-1-infected T-cell $\stackrel{\circ}{\circ}$ lines, ${ }^{13}$ and in tumour cells from ATLL patients with hypercalcaemia. ${ }^{14}$ Enhanced expression of the

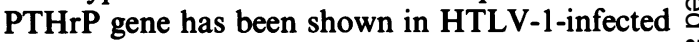
T-cells both in asymptomatic HTLV-1 carriers and के in ATLL patients, but not in normal T-cells. ${ }^{15} \vec{\circ}$ Furthermore the HTLV-1 'tax' gene has been shown to transactivate the PTHrP gene promoter $\vec{\omega}$ in co-transfection assays, and it is suggested that further activation of the gene during malignant transformation to ATLL may occur, thus accounting for the high incidence of hypercalcaemia in ATLL patients.

This is the first report of high circulating serum levels of PTHrP in a patient with HTLV-1-positive human adult T-cell leukaemia-lymphoma. Previous reports of elevated serum levels have been restricted to solid tumours associated with hypercalcaemia. ${ }^{6}$ The response to bisphosphonates reflected the probable role of PTHrP in causing the hypercalcaemia. It remains unclear whether other tumour products may also be involved in the $\stackrel{\mathbb{Q}}{\triangle}$ development of hypercalcaemia in ATLL. The $\vec{\bullet}$ elevated 1,25-dihydroxycholecalciferol probab contributed to this patient's hypercalcaemia, ind? cating that the aetiology of HMM may be multifactorial. However, the in vitro evidence for PTHrP expression in these patients along with this report of elevated serum levels strongly implicate PTHrP as one mediator of the hypercalcaemia associated with ATLL.

\section{Acknowledgements}

We are grateful to Dr W.A. Ratcliffe, Department of Medicine, Queen Elizabeth Hospital, Birmingham, for performing the PTHrP assay, to Dr M. Hewison, Department of Medicine, Middlesex Hospital, London, for 3 performing the 1,25-dihydrocholecalciferol assay, and to Dr J. Cohen, Reader in Infectious Diseases, Hammersmith Hospital, who looked after the patient.

\section{References}

1. Catovsky, D., Greaves, M.F., Rose, M. et al. Adult T-cell leukaemia-lymphoma in blacks from the West Indies. Lancet 1982 , i: $639-643$

2. Karmali, R., Barker, S., Hewson, M. et al. Intermittent hypercalcaemia and vitamin D sensitivity in Hodgkin's disease. Postgrad Med J 1990, 66: 757-760.

3. Breslau, N.A., McGuire, J.L., Zerwekh, J.E. et al. Hypercalcaemia associated with increased serum calcitriol levels in three patients with lymphoma. Ann Intern Med 1984, 100: 1-7.

4. Fetchick, D.A., Bertolini, D.R., Sarin, P.S. et al. Production of 1,25-dihydroxyvitamin D3 by human T-cell lymphotropic virus-1 transformed lymphocytes. J Clin Invest 1986, 78: $592-596$. 
9. Bundred, N.J., Ratcliffe, W.A., Walker, R.A. et al. Parathyroid hormone related protein and hypercalcaemia in breast cancer. $\mathrm{Br}$ Med J 1991, 303: 1506-1509.

10. Kao, P.C., Klee, G.C., Taylor, R.L. \& Heath, H. Parathyroid hormone-related peptide in plasma of patients with hypercalcaemia and malignant lesions. Mayo Clin Proc 1990, 65: 1399-1407.

11. Dodd, R.C., Winkler, C.F., Williams, M.E. et al. Calitriol levels in hypercalcaemic patients with adult $\mathrm{T}$-cell lymphoma. Arch Intern Med 1986, 146: 1971-1972.

12. Moseley, J.M., Danks, J.A., Grill, V., Lister, T.A. \& Horton, M.A. Immunocytochemical demonstration of PTHrP protein in neoplastic tissue of HTLV-1 positive human adult T cell leukaemia-lymphoma-implications for the mechanism of hypercalcaemia. Br J Cancer 1991, 64: 745-748.
13. Motokura, T., Fukumoto, S., Takahashi, S. et al. Expression of parathyroid hormone-related protein in a human T-cell lymphotrophic virus type-1 infected T-cell line. Biochem Biophys Res Commun 1988, 154: 1182-1188.

14. Motokuru, T., Fukumoto, S., Matsumoto, T. et al. Parathyroid hormone-related protein in human T-cell leukaemia lymphoma. Ann Intern Med 1989, 111: 484-488.

15. Watanbe, T., Yamaguchi, K., Takatsuki, K. et al. Constitutive expression of parathyroid hormone-related protein in human T-cell leukaemia virus Type-1 (HTLV-1) carriers and adult $\mathrm{T}$-cell leukaemia patients that can be transactivated by HTLV-1 tax gene. J Exp Med 1990, 172: 759-765. 